\title{
An Enzyme-Linked Immunoassay of Surfactant Apoproteins. Its Application to the Study of Fetal Lung Development in the Rat
}

\author{
SIKANDAR L. KATYAL ${ }^{(25)}$ AND GURMUKH SINGH \\ Department of Pathology, School of Medicine, University of Pittsburgh, Pittsburgh, Pennsylvania, USA
}

\begin{abstract}
Summary
Rat lung surfactant contains glycoproteins with molecular weights of about $38,000,32,000$ and 26,000 , which are not of serum origin and appear to form an integral part of surfactant as its apoproteins. An enzyme-linked immunoassay for these apoproteins has been developed, in which the antigen is sandwiched between specific antibodies raised in two different species. The assay is capable of measuring 10-160 $\mathrm{ng}$ of the apoproteins per $\mathrm{ml}$ of lung homogenate or amniotic fluid with a coefficient of variation of less than $5 \%$. The immunoassay has been used to quantitate apoproteins in rat lungs during pre- and postnatal development, as well as in amniotic fluids at different stages of pregnancy. The apoproteins become detectable in the lungs of 18-day-old fetuses. The lung content of apoproteins increases 4-fold in 19-day-old fetuses, 18-fold in 20-day-old fetuses and 38-fold in 21-day-old fetuses. The lungs of newborn rats contained twice as much apoproteins as the lungs of 21-day-old fetuses. During the postnatal period, the apoprotein content of the lung showed a 3-fold increase in adults as compared to newborn rats. Apoproteins could be detected for the first time in the amniotic fluids of 19-day-old pregnant rats, and their concentration rose 2-3-fold at 20 and 21 days of pregnancy. Our results in this study show that surfactant apoproteins, like pulmonary surfactant lipids, appear in fetal lungs during the late stages of gestation and their amounts increase rapidly as gestation progresses. Furthermore, presence of surfactant aproproteins in fetal lungs can be monitored by quantitation of apoproteins in amniotic fluids during late stages of pregnancy.
\end{abstract}

\section{Abbreviations}

PBS-NP, phosphate buffered saline, pH 8.0, containing $0.5 \%$ Nonidet P-40.

RDS, respiratory distress syndrome.

SDS-polyacrylamide, sodium dodecyl sulfate polyacrylamide.

SS-IgG, rabbit and guinea pig antisurfactant IgG

Pulmonary surfactant lines the alveoli of the lung and is essential for maintaining alveolar patency. A deficiency of this material is believed to be the major cause of respiratory distress syndrome in human neonates. Pulmonary surfactant is synthesized, stored, and secreted by alveolar epithelial type II cells of the lung (1), and is rich in phospholipids, especially dipalmitoyl phosphatidylcholine $(2,8)$. Whether or not surfactant phospholipids are associated with specific apoproteins, and are secreted in the form of a lipoprotein, has been controversial (18). In recent years, however, evidence has been obtained in several laboratories that certain proteins are specifically associated with the surfactant and that these, therefore, should be considered as apoproteins $(2,6,7-12$, $16,17,19,20,24)$. Indeed, antibodies prepared against rat surfactant apoproteins and used in an immunoperoxidase method could stain the material lining the alveoli as well as the type II cells (6).
Using this technique, surfactant apoproteins were found to appear in fetal rat lungs at a gestational age at which type II cells are known to differentiate and to begin to store surfactant in the form of lamellar bodies (6). An increase in the number of positive cells and staining intensity were also seen with increasing gestational age (6). But, the immunoperoxidase technique proved to be useful only for the study of qualitative alterations of surfactant apoproteins during fetal lung development. In this communication, the development of an enzyme-linked immunoassay for the quantitation of rat surfactant apoprotein(s) is reported. The method has been used to measure surfactant apoproteins in rat lung during pre- and postnatal development and in rat amniotic fluids.

\section{MATERIALS AND METHODS}

Animals. Adult male and timed-pregnant female rats of the Sprague Dawley strain were obtained from Zivic Miller, Allison Park, PA. Fetuses were delivered by cesarean sections at 17-21 days of gestation. Amniotic fluid was collected from pregnant rats by puncturing individual amniotic sacs at 17-21 days of gestation. Male rabbits, New Zealand strain and weighing 2-2.5 kg, were supplied by Edward McCarthy, Conneaut Lake, PA. Guinea pigs of the Hartley strain, weighing $250 \mathrm{~g}$, were obtained from Hilltop Laboratories, Scottdale, PA.

Preparation of anti-rat surfactant IgG. Lungs of adult rats were lavaged with $0.15 \mathrm{M} \mathrm{NaCl}$ containing $0.25 \mathrm{mM}$ phenylmethylsulfonyl fluoride (5). Surfactant was isolated and purified from the lavages as detailed elsewhere (5). Briefly, the method consists of removal of cell and cell debris from lavage fluid by low speed centrifugation, followed by high speed centrifugation $(19,500 \times \mathrm{g}$ for $35 \mathrm{~min}$ ) of the cell-free supernatant to obtain a surfactant rich pellet. The pellet is resuspended and introduced in a discontinuous density gradient prepared from $\mathrm{NaCl}-\mathrm{NaBr}$ solutions. The gradient is centrifuged at $65,000 \times \mathrm{g}$ for $90 \mathrm{~min}$. Surfactant is thus obtained as a band at a density of 1.078 . The material in the band is diluted with water and recentrifuged at $19,500 \times \mathrm{g}$ for $35 \mathrm{~min}$. Pulmonary surfactant, thus pelleted, was used to raise specific antisera in rabbits and guinea pigs (6). Suspension in normal saline of purified surfactant was emulsified with equal volumes of Freund's complete adjuvant. Emulsion, containing $500 \mu \mathrm{g}$ of surfactant proteins, were injected into food pads and neck nape of the animal. Starting 10 days later, surfactant ( $1 \mathrm{mg}$ protein) in saline was injected subcutaneously once a week for 3 wk. The animals were bled and the antisera collected $1 \mathrm{wk}$ after the last injection. An immunoglobulin $\mathrm{G}$ fraction was prepared from each antisera by ammonium sulfate precipitation and DEAE cellulose column chromatography (14).

Absorption of antirat surfactant IgG. In order to remove antibodies directed at rat serum proteins, rabbit and guinea pig antirat surfactant IgG fractions were subjected to affinity chromatography on Sepharose-linked rat serum as reported earlier (6). Cyanogen bromide-activated Sepharose was coupled to rat serum proteins. Antisurfactant IgG (raised in rabbit or guinea pig), dissolved 
in $0.02 \mathrm{M}$ phosphate- $0.15 \mathrm{M} \mathrm{NaCl}, \mathrm{pH} 8.0$, was passed through columns of serum proteins bound to activated Sepharose in order to remove antibodies to serum proteins. IgG, not bound by the columns, was collected. Further absorptions of guinea pig and rabbit IgG fractions were carried out on columns of Sepharoselinked rabbit serum and Sepharose-linked guinea pig serum, respectively. The resultant IgG preparations were tested by agar gel immunodiffusion for reactivity to surfactant and serum of rat and to each other. Rabbit and guinea pig antisurfactant IgG (SSIgG) fractions were used in the immunoassay as well as for preparing bulk quantities of rat surfactant apoproteins.

Preparation of surfactant apoproteins. Rat surfactant apoproteins, to be used as standard in the immunoassay, were prepared in the following manner. Surfactant, isolated from lung lavage fluid, was solubilized in $0.1 \mathrm{M}$ phosphate- $\mathrm{k}$-ffered saline, $\mathrm{pH} 8.0$, containing $0.5 \%$ Nonidet P-40 (Bethesda Research Laboratories, Bethesda, MD), and was subjected to affinity chromatography on a column of Sepharose-linked (rabbit or guinea pig) antirat SSIgG (7). Proteins not bound to the column were washed out with phosphate-buffered saline, and bound proteins (surfactant apoproteins) were eluted with $3 \mathrm{M} \mathrm{KSCN}$. The KSCN eluate was dialyzed extensively against distilled water, and the proteins were lyophilized and redissolved in phosphate buffered saline. The proteins were further analysed by sodium dodecyl sulfate polyacrylamide (SDS-polyacrylamide) gel electrophoresis (13). Protein estimations were carried out according to the method of Lowry $t t$ al. (15).

Immunoassay. The protocol for the immunoassay is shown diagrammatically in Figure 1. Polystyrene tubes $(12 \times 75 \mathrm{~mm}$, Fisher Scientific, Pittsburgh, PA) containing $0.2 \mathrm{ml}$ of guinea pig antirat SS-IgG (antibody preparation diluted with phosphatebuffered saline; protein: $50 \mu \mathrm{g} / \mathrm{ml}$ ) were incubated overnight at $37^{\circ} \mathrm{C}$. The tubes were then washed extensively with $0.1 \mathrm{M}$ phosphate buffered saline, $\mathrm{pH} 8.0$, containing $0.5 \%$ Nonidet P-40 (PBSNP). Aliquots $(0.2 \mathrm{ml})$ containing 5-320 $\mathrm{ng}$ of the affinity-purified apoproteins per $\mathrm{ml}$ (in PBS-NP) were added to the antibodycoated tubes. The tubes were incubated at $24^{\circ} \mathrm{C}$ for $1 \mathrm{~h}$ and washed with PBS-NP. Aliquots $(0.2 \mathrm{ml})$ of rabbit antirat SS-IgG (50-60 $\mu \mathrm{g}$ protein $/ \mathrm{ml}$ ) in PBS-NP were then added to each tube, followed by incubation at $24^{\circ} \mathrm{C}$ for $1 \mathrm{~h}$. After washings with PBS$\mathrm{NP}$, a further incubation was carried out for $1 \mathrm{~h}$ with $0.2 \mathrm{ml}$ of alkaline phosphatase conjugated goat antirabbit IgG antiserum (Miles Laboratories, Elkhart, IN; diluted 1200 times). After washings with PBS-NP and PBS alone, $1 \mathrm{ml}$ of reaction mixture [0.05 $\mathrm{M}$ sodium carbonate buffer, $\mathrm{pH} 9.8$, containing $1 \mathrm{mM} \mathrm{MgCl}_{2}$ and $3.8 \mathrm{mM}$ p-nitrophenylphosphate, (Sigma Chemicals, St. Louis, MO)] was added. The reaction was carried out for $15-40 \mathrm{~min}$ at room temperature, and was stopped by addition of $0.2 \mathrm{ml}$ of $1 \mathrm{~N}$ $\mathrm{NaOH}$. Optical density of the reaction mixture was measured at $400 \mathrm{~nm}$. Controls in which the antigen was omitted were included with each run.

Immunoassay of surfactant apoproteins in rat lung and amniotic fluid. Measurement of apoproteins in fetal, newborn, and adult rat lung was performed in the following manner. Lungs obtained from rat fetuses (17-21 days of gestation), and newborn and adult rat lungs were homogenized in $0.1 \mathrm{M}$ phosphate buffered saline, containing $0.5 \%(\mathrm{w} / \mathrm{v})$ Nonidet P40, using a Polytron Model PT10 (Brinkman Instruments, Westbury, NY). The homogenates (5$10 \% \mathrm{w} / \mathrm{v}$ ) were centrifuged (International Refrigerated Centrifuge PR-2, rotor 269) at $600 \mathrm{rpm}$ for $15 \mathrm{~min}$. The supernatants were used for immunoassay after serial dilutions (undiluted to 1:512) with PBS-NP. Nonidet P-40 was mixed with amniotic fluids to a final concentration of $0.5 \%$. The mixture was centrifuged for 1 min in an Epindorff Centrifuge, Model 5412 (Brinkman Instruments, Westbury, NY). The supernatant was collected and used for immunoassay after serial dilutions (undiluted to $1: 256$ ) with PBS-NP.

\section{RESULTS}

Specificity of the antisera. The specificity of the two primary antibodies (guinea pig and rabbit antirat surfactant specific IgG) was tested first by agar gel immunodiffusion. A single precipitin line was obtained by interaction of each antibody with rat surfactant. On the other hand, the antibodies did not react with rat serum proteins. To further test the specificity of the primary antibodies, immunoaffinity chromatography of pulmonary surfactant was carried out on columns of Sepharose-linked rabbit or guinea pig antirat surfactant specific IgG. The bound proteins were eluted from each column, chemically reduced with dithiothreitol and subjected to SDS-polyacrylamide gel electrophoresis. Three protein bands (molecular weights $38,000,32,000$, and 26,000 ) were present in the Coomassie blue stained gels (data not shown here, see ref. 7). The results show that the primary antibodies were specific for surfactant apoproteins, namely the 38,000 , 32,000 and 26,000 dalton proteins.

Imn xnoassay of apoproteins. The apoproteins (the combined $38,000,32,000$ and 26,000 dalton glycoproteins), used as standard for the immunoassay, had not suffered, during affinity purification, any significant irreversible denaturation, or loss of antigenicity as a result of elution with a $3 \mathrm{M} \mathrm{KSCN}$ solution from columns of Sepharose linked SS-IgG. The reason for the lack of irreversible denaturation is based on the observation that in the surfactant isolated from rat lung lavage fluid, surfactant apoproteins (quantitated, using affinity-purified apoproteins as standard) and serum proteins (quantitated after affinity-purification on columns of Sepharose linked anti-rat serum antiserum), together, account for all the proteins present in the surfactant. A significant loss of antigenicity of surfactant apoproteins by elution with $3 \mathrm{M}$ KSCN would have resulted in overestimation of the apoproteins.

The assay was capable of measuring 10-160 ng of apoproteins/ $\mathrm{ml}$ (Fig. 2) with a coefficient of variation of less than $5 \%$. The calibration curve obtained with different concentrations of apoprotein standard and that from different dilutions of purified surfactant are very similar (Fig. 3). When rabbit antirat surfactant
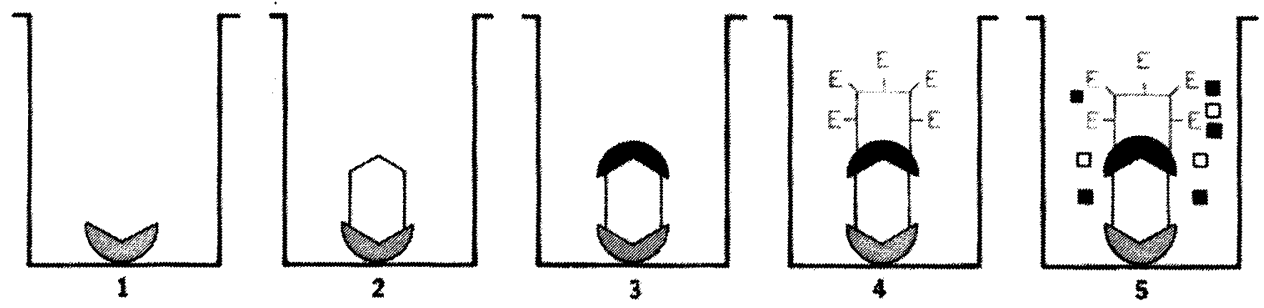

Fig. 1. Protocol of enzyme-linked immunoassay for surfactant apoproteins. (1) Guinea pig antirat surfactant apoproteins specific IgG (SSIgG) is absorbed on polystyrene surface. (2) The antigen is bound to the antibody. (3) The antigen is sandwiched between rabbit SSIgG and guinea pig SSIgG. (4) Alkaline phosphatase linked goat anti-rabbit IgG antibody binds to the complex. (5) Alkaline phosphatase activity is measured in the presence of p-nitrophenyl phosphate substrate. 


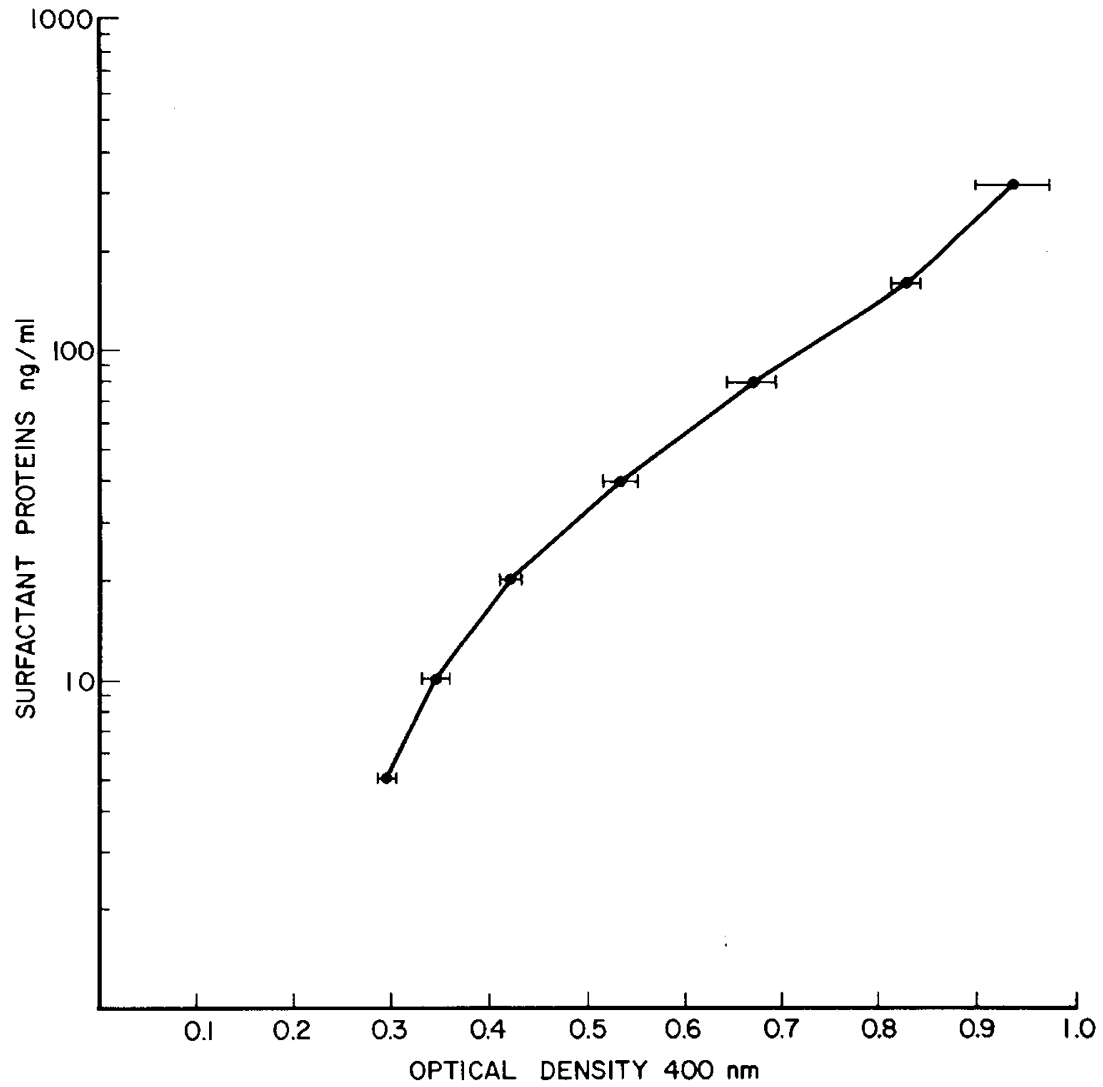

Fig. 2. Enzyme-linked immunoassay of affinity-purified surfactant apoproteins (molecular weights of about 38,000, 32,000, and 26,000). The assay can be used to quantitate 10-160 ng surfactant apoproteins per ml. Each point represents the mean \pm l S.D. of three determinations.

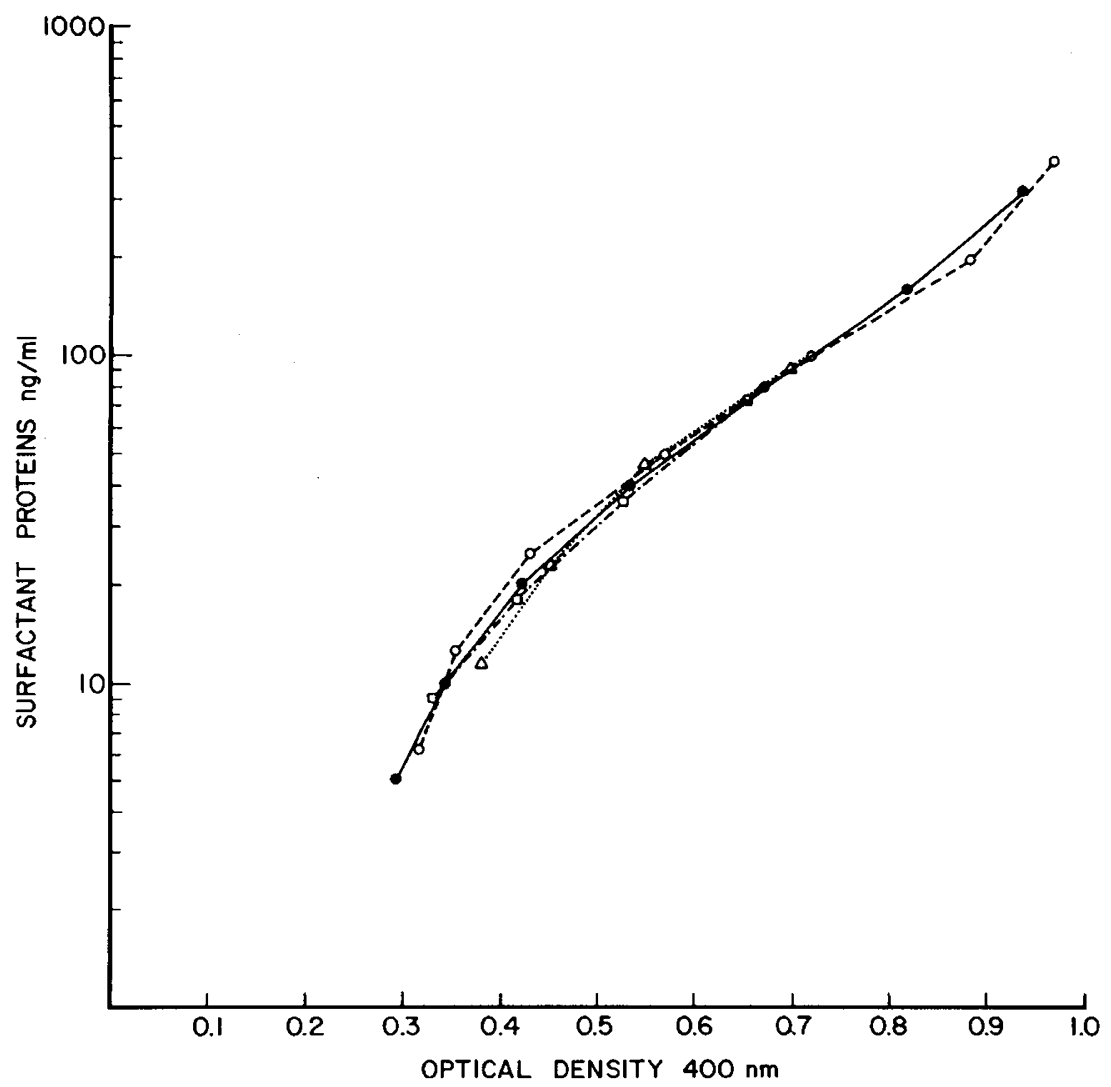

Fig. 3. Comparison of calibration curves obtained for dilutions of a lung homogenate from 20-day-old rat fetus ( $\square-.-$. $\square$ ), or of amniotic fluid from 20-day pregnant rat $(\Delta \cdots \cdots \Delta)$, or of surfactant purified from rat lung lavage fluid $\left(\mathrm{O}_{-}--_{-}\right)$, and affinity purified surfactant apoproteins $(0)$. 
specific $\operatorname{IgG}$ is replaced by nonimmune rabbit $\operatorname{IgG}$ in the assay, only baseline values were obtained with increasing concentrations of apoprotein standard. Addition of rat serum (10 times diluted) to the standard apoprotein preparation did not change the assayed concentration of apoprotein. These results show that the immunoassay is specific for the surfactant apoproteins and is free of interference from other proteins.

Delipidation (6) of the purified surfactant before its use in the immunoassay had virtually no effect on the immunoassay. For higher sensitivity, however, the assay required the presence of a nonionic detergent, Nonidet P-40, during incubation of the antigen with the antibody bound to polystyrene. We have used the assay to measure apoproteins in surfactant isolated from lung lavage fluids and from homogenates of rat lungs. Surfactant purified from lung lavage fluid contains about $63 \%$ of the total proteins as surfactant apoproteins. Surfactant purified from lung homogenates, on the other hand, contains about $29 \%$ of the total proteins as apoproteins.

Immunoassay of aproproteins in the lungs and amniotic fluid of rat. A $5 \%(\mathrm{w} / \mathrm{v})$ homogenate of the lungs of 20-day-old fetuses and a sample of amniotic fluid from a 20 -day pregnant rat were serially diluted. Each dilution was then used for measuring surfactant apoproteins. The results show that the calibration curve obtained with different dilutions of lung homogenate and of amniotic fluid and that from different concentrations of apoproteins standard are very similar (Fig. 3). The concentration of apoprotein in each of the diluted samples of lung homogenate and the amniotic fluid differed within a narrow range. The mean content of apoproteins at 1:8 to 1:64 dilutions of the homogenate was $23.3 \mu \mathrm{g} / \mathrm{g}$ wet lung with a S.D. of 1.16 . On the other hand, the concentration of apoproteins in rat amniotic at 1:16 to $1: 56$ dilutions of the amniotic fluid was $670 \pm 10.88 \mathrm{ng} / \mathrm{ml}$ (mean \pm S.D.).

Ontogeny of surfactant apoproteins. The immunoassay was used to measure surfactant apoproteins in the lungs of fetal, newborn, and adult rats. The results are shown in Table 1 . No apoprotein could be detected in the lungs of 17-day-old fetuses. The optical density values obtained at all dilutions $(1: 8-1: 128)$ of the $5 \%$ (w/ v) lung homogenates were similar to those derived from negative controls (no antigen added). The 18-day-old fetal lungs contained about $1 \mu \mathrm{g}$ of surfactant apoproteins/g wet tissue. A 4-fold increase was observed in 19-day-old fetuses; 18-fold in 20-day-old fetuses; and about 38-fold in 21-day-old fetuses. The lungs of newborn rats contained twice as much surfactant apoprotein as the lungs of 21-day-old fetuses. During the postnatal period, the apoprotein content of the lungs rose and showed a 3 -fold increase in adult rats as compared to newborn rats.

Apoproteins were measured also in rat amniotic fluids, collected at different times of pregnancy (Table 2). Apoproteins could not be detected in the amniotic fluids of 17-day and 18-day pregnant rats. They were detected for the first time at 19 days of pregnancy and their concentration increased $2-3$-fold at days 20 and 21 days of pregnancy.

\section{DISCUSSION}

The immunoassay, reported here, involves the use of primary antisera raised in two different animal species. The primary anti-

Table 1. Immunoassay of surfactant apoproteins in rat lungs ${ }^{1}$

\begin{tabular}{|c|c|c|}
\hline & Body weight(g) & $\begin{array}{c}\mu \mathrm{g} \text { apoproteins/g we } \\
\text { lung }\end{array}$ \\
\hline \multicolumn{3}{|l|}{ Fetuses } \\
\hline 18 day & $1.31 \pm 0.02(15)$ & $1.18,1.2$ \\
\hline 19 day & $2.14 \pm 0.02(12)$ & $4.87 \pm 0.12(3)$ \\
\hline 20 day & $3.81 \pm 0.07(16)$ & $22.42 \pm 1.95(5)$ \\
\hline 21 day & $5.47 \pm 0.11(14)$ & $46.23 \pm 3.62(5)$ \\
\hline Newborn rats (1-day-old) & $7.26 \pm 0.21(10)$ & $105.5 \pm 7.75(6)$ \\
\hline Adult rats & $200-450$ & $317.4 \pm 19.42(4)$ \\
\hline
\end{tabular}

${ }^{1}$ Values are expressed as mean \pm S.E. of the number of animals or of pools of tissue given in parentheses.
Table 2. Immunoassay of surfactant apoproteins in rat amniotic fluid $^{1}$

\begin{tabular}{cc}
\hline Duration of pregnancy (days) & (ng apoproteins $/ \mathrm{ml}$ ) \\
\hline 18 & not detected \\
19 & $218 \pm 16.0(3)$ \\
20 & $590 \pm 51.8(4)$ \\
21 & $456 \pm 32.3(3)$ \\
\hline
\end{tabular}

${ }^{1}$ Values are expressed as mean \pm S.E. of the number of pools of amniotic fluid given in parentheses.

bodies (rabbit and guinea-pig antirat surfactant IgG) used in the assay were each specific for the three rat surfactant apoproteins, i.e., $38,000,32,000$ and 26,000 dalton glycoproteins (7). The immunoassay thus measures the combined content of these apoproteins. The assay is sensitive in the range of $10-160 \mathrm{ng}$ of apoproteins $/ \mathrm{ml}$ and is reproducible with a coefficient of variations of $5 \%$ or less. Completion of the immunoassay requires about $5 \mathrm{~h}$ after the tubes used in the assay have been precoated with the primary antibody. Delipidated surfactant and surfactant containing an excess of serum proteins can be used in the immunoassay without loss of sensitivity and accuracy.

To validate it further, the assay was used to measure the surfactant apoproteins of rat lungs and amniotic fluids during lung development. As shown in Table 1, surfactant apoproteins were detected first in lungs of 18-day-old fetuses. Thereafter, a progressive increase was seen parallel to that of the gestational age. These results are in agreement with those of previous biochemical and morphologic studies on the ontogenesis of pulmonary surfactant in rat $(6,22,23)$. Postnatally, a 3 -fold increase in the apoprotein content of rat lung is seen in adult as compared to newborn animals (Table 2). We have not yet determined whether this increase is intra- or extracellular. In rats, much of the alveolar development occurs postnatally, increasing the demand for extracellular surfactant. Whether or not this increased demand of surfactant is met by an increased number of alveolar type II cells, by increased biosynthesis and/or secretion of surfactant is not clear as yet.

Pulmonary surfactant apoproteins were detected in the amniotic fluid of rats as early as day 19 , one day after it had been detected in the lung (Table 2). Highest concentrations of apoproteins were noted in the amniotic fluids of 20 -day pregnant dams. On day 21 , a slight decrease is seen, whereas the apoprotein content of the lung is increased 2-fold. The reason for this decrease is not known. Whether or not this represents reabsorption of the proteins or their destruction by enzymes present in amniotic fluid or loss of antigenecity of surfactant proteins, is not clear. Furthermore, it is possible that the increase in apoprotein content of the lung in 21day fetuses may have been due mainly to an increased intracellular storage of the surfactant. The presence of surfactant apoprotein in amniotic fluid during the later stages of gestation has been previously shown by King et al. (10) in humans.

The present results, clearly demonstrate that surfactant apoproteins can serve as a marker of pulmonary surfactant and can be used to monitor the physiologic changes of the latter. The use of apoproteins to assess surfactant alterations in pathologic conditions has not been explored as yet. Phospholipid analysis of human amniotic fluids is generally employed to measure fetal lung maturity and to predict the risk of respiratory distress syndrome in the newborn $(3,4,21)$. Assay of surfactant apoproteins in the same fluids may provide an alternate and more specific method for the same purpose, and this application of the present assay is being currently investigated in this laboratory.

\section{REFERENCES AND NOTES}

1. Askin, F. B. and Kuhn, C.: The cellular origin of pulmonary surfactant. Lab Invest., 25: 260 (1959).

2. Clements, J. A. and King, R. J.: Composition of surface active material. In: R. G. Crystal, Ed.: The Biochemical Basis of Pulmonary Function. pp. 363-387 (Marcel Dekker, New York, NY, 1976).

3. Clements, J. A. and Tooley, W. H.: Kinetics of surface active material in the fetal lung. In: W. A. Hodson, Ed.: Development of the Lung. pp. 356-366 (Marcel Dekker, New York, NY, 1977). 
4. Gluck, L. and Kulovich, M. V.: Maturation of the fetal lung, RDS, and amniotic fluid. In: C. A. Villee, D. B. Villee, and J. Zuckerman, Eds.: Respiratory Distress Syndrome. pp. 183-204 (Academic Press, New York, NY, 1973).

5. Katyal, S. L., Estes, L. W., and Lombardi, B.: Method for the isolation of surfactant from homogenates and lavages of lung of adult, newborns and fetal rats. Lab. Invest., 36: 585 (1977).

6. Katyal, S. L. and Singh, G.: An immunologic study of the apoproteins of rat lung surfactant. Lab. Invest., 40: 562 (1979).

7. Katyal, S. L. and Singh, G.: Analysis of pulmonary surfactant apoproteins by electrophoresis. Biochim. Biophys. Acta, 670: 323 (1981).

8. King, R. J.: The surfactant system of the lung. Fed. Proc. 33: 2238 (1974).

9. King, R. J., Gikas, E. G., Ruch, J., and Clements, J. A.: The radioimmunoassay of pulmonary surface active material in sheep lung. Am. Rev. Respir. Dis., 110: 273 (1974)

10. King, R. J., Ruch, J., Gikas, E. G., Platzker, A. C. G., and Creasy, R. K.: Appearance of apoproteins of pulmonary surfactant in human amniotic fluid. Appl. Physiol., 39: 735 (1975).

11. King, R. J., Martin, H., Mitts, D., and Holmstrom, F. M.: Metabolism of the apoproteins in pulmonary surfactant. J. Appl. Physiol. 42: 483 (1977).

12. King, R. J. and Martin, H.: Intracellular metabolism of the apoproteins of pulmonary surfactant in rat lung. J. Appl. Physiol. 48: 812 (1980).

13. Laemmli, U. K.: Cleavage of structural proteins during the assembly of the head of bacteriophage. T4. Nature, 227: 680 (1970).

14. Livingston, D. M.: Immunoaffinity chromatography of proteins. Methods. Enzymol., 34: 723 (1974).

15. Lowry, O. H., Rosbrough, N. J., Farr, A. L., and Randall, R. J.: Protein measurement with the folin phenol reagent. J. Biol. Chem., 193: 265 (1951).

16. Phizackerley, P. J. R., Town, M. H., and Newman, G. E.: Hydrophobic proteins of lamellated osmiophilic bodies isolated from pig lung. Biochem. J., 183: 731 (1979).

Copyright @ 1983 International Pediatric Research Foundation, Inc 003l-3998/83/1706-0439\$02.00/0
17. Sawada, H. and Kashiwamata, S.: Sodium dodecyl sulfate disc gel electrophoresis patterns of bovine lung surfactant. Biochim. Biophys. Acta. 490: 44 (1977).

18. Shelley, S. A., L'Heureux, M. V., and Balis, J. U.: Characterization of lung surfactant: factors promoting formation of artifactual lipid protein complexes. J. Lipid Res., 16: 224 (1975).

19. Sueishi, K., Tanaka, K., and Oda, T.: Immunoultrastructural study surfactant system distribution of specific protein of surface active material in rabbit lung Lab. Invest., 37: 136 (1977).

20. Sueischi, K. and Benson, B. J.: Isolation of a major apolipoprotein of canine and murine pulmonary surfactant. Biochemical and immunochemical characterists. Biochim. Biophys. Acta, 665: 442 (1981)

21. Torday, J., Carson, L., and Lawson, E. E.: Saturated phosphatidylcholine in amniotic fluid and prediction of the respiratory distress syndrome. N. Engl. J. Med., 301: 1013 (1979).

22. Williams, M. C. and Mason, R. J.: Development of the type II cells in the fetal rat lung. Am. Rev. Respir. Dis., 115: 37 (1977).

23. Williams, M. C.: Development of the alveolar structure of the fetal rat in late gestation. Fed. Proc., 36: 2653 (1977).

24. Williams, M. C. and Benson, B. J.: Immunocytochemical localization and identification of the major surfactant protein in adult rat lung. J. Histochem. Cytochem. 29: 291 (1981).

25. Requests for reprints should be addressed to: Dr. S. L. Katyal, Department of Pathology, School of Medicine, University of Pittsburgh, Pittsburgh, PA 15261.

26. This work was supported by grants from the National Heart, Lung and Blood Instituter (HL17199), the National Cancer Institute (CA2708) and Samuel Emma Winters Foundation. Diane Christy provided excellent technical assistance.

27. Received for publication March 25, 1982

28. Accepted for publication September 20, 1982. 